\title{
THE COMPARISON OF ANKLE BRACHIAL INDEX IN PATIENTS WITH AND WITHOUT ACS IN PROF. DR. R. D. KANDOU HOSPITAL, MANADO
}

\author{
Elfan Moeljono \\ Iman Y. Suhartono, Terrance Ransun, Fonny M. Tedjo, \\ Agnes L. Panda, Reginald L. Lefrandt \\ Department of Cardiology and Vascular Medicine \\ Faculty of Medicine University of Sam Ratulangi Manado \\ Email: elfan.moeljono@yahoo.com
}

\begin{abstract}
Abstrak: Walaupun merupakan pengukuran sederhana dan non-invasif, ankle brachial index (ABI) menunjukkan sensitifitas dan spesifisitas yang tinggi dalam mendiagnosis penyakit arteri perifer pada nilai $\mathrm{ABI} \leq 0,9$. ABI juga merupakan indikator yang kuat untuk mengetahui penyakit aterosklerosis pada area vaskular lainnya. Penelitian ini bertujuan untuk menentukan perbandingan antara $\mathrm{ABI}$ pada pasien dengan atau tanpa sindroma koroner akut (SKA). Penelitian ini menggunakan analisis analitik observasional dengan desain potong lintang. Subyek penelitian ialah pasien dengan SKA dan pasien tanpa SKA yang datang ke Departemen Kardiologi dan Pembuluh Darah RSU Prof. Dr. R.D Kandou, Manado bulan September-Desember 2012. Nilai normal ABI yaitu $>0,9$ dan $<1,4$, sedangkan ABI <0,9 perlu dipertimbangkan abnormal. Nilai ABI $>1,4$ dipertimbangkan tidak valid dan diekslusi. Hubungan antara variabel dievaluasi menggunakan SPSS. Hasil penelitian memperlihatkan 33 pasien SKA (72,8\% laki-laki) dan 33 pasien tanpa SKA (81,8\% laki-laki) sebagai subyek penelitian. Rerata usia pasien SKA 57 tahun dan tanpa SKA 52,3 tahun. Angka kejadian pasien SKA dengan ABI abnormal lebih tinggi, yaitu $82,1 \%$ vs $17,9 \%(P<0,001)$. Uji chisquare menunjukkan terdapatnya hubungan antara SKA dan peningkatan risiko ABI abnormal (OR 12, $P<0,05$ ). Simpulan: Sindroma koroner akut berhubungan dengan peningkatan risiko dari $\mathrm{ABI}$ abnormal.
\end{abstract}

Kata kunci: Ankle brachial index, sindroma koroner akut.

\begin{abstract}
Although the ankle-brachial index (ABI) is a simple and non-invasive measurement, it shows a high sensitivity and specificity in the diagnosis of peripheral arterial disease (PAD) when its value is $\leq 0.9$. Moreover, $A B I$ is a powerful indicator of atherosclerotic diseases in other vascular areas. This study aimed to determine the comparison between ankle brachial indices (ABI) in patients with or without acute coronary syndrome (ACS). This was an analytical observational study with a cross sectional design. We measured ABI indices in 33 patients with ACS and 33 patients without ACS admitted to the Department of Cardiology and Vascular Medicine, Prof. Dr. R.D. Kandou Hospital, Manado. The normal ABI is $>0.9$ and $<1.4$. However, ABI $<0.9$ was considered as abnormal. On the other hand, ABI $>1.4$ was considered invalid and then excluded. The association of variables was evaluated by SPSS software. The results showed that there were 33 ACS patients (72.8\% male) and 33 patient without ACS (81.8\% male). ACS patients were older (57 vs 52.3 years). ACS patients had more prevalent abnormal ABI ( $82.1 \%$ vs $17.9 \% ; P<$ $0.001)$. Chi square test showed that ACS was associated with an increased risk of abnormal ABI (OR 12, $P<0.05)$. Conclusion: ACS was associated with an increased risk of abnormal ABI.
\end{abstract}

Keywords: ankle brachial index, acute coronary syndrome. 
Atherosclerosis is the main cause of mortality today. Acute coronary syndrome (ACS) is a series of cardiovascular emergencies based on pathological findings, ranging from the rupture of the atheromatous plaques to acute thrombosis in coronary arteries, which threatens human lives. ${ }^{1,2}$ The presence of peripheral arterial disease (PAD) in patients with coronary artery disease is associated with a poor cardiovascular outcome. ${ }^{2}$ The anklebrachial index (ABI), a simple and noninvasive measurement, shows a high sensitivity and specificity in the diagnosis of PAD when its value is $\leq 0.9 .^{1}$ Recent studies also showed that ABI was a powerful indicator of atherosclerotic disease in other vascular areas and of increased cardiovascular morbidity and mortality. ${ }^{1-3}$ ABI can predict the future severity of coronary artery stenosis which is closely related to cardiovascular events and deaths. ${ }^{1}$ This study was designed to discuss the comparison between ABI in patients with and without ACS.

\section{METHODS}

This was an analytical observational study with a cross sectional design. The inclusion criteria of this study were patients admitted to the hospital with ACS, defined as: typical chest pain; electrocardiographic changes showing ischemia or myocardial lesions; and/or an increased level of myocardial damage markers.

The ABI was used to measure both sides of the body using a pocket Vascular Doppler 8 Mhz RFD-E ${ }^{\circledR}$ device and a blood pressure cuff following the established recommendation. The systolic blood pressure was measured in both arms (brachial arteries) and both ankles (posterior tibial arteries) with the patient in the supine position. The ABI for each leg was calculated by dividing the systolic pressure of the right and left ankles by the highest systolic pressure recorded in either arm. The lowest ABI value for each patient was determined. A pathological ABI was considered if its value was of either $>1.4$ or $\leq 0.9$. $^{1}$ Each center was equipped with an identical Doppler device and specific training in the measurement of $\mathrm{ABI}$ was given to all researchers to guarantee the coherence of the results. An ABI of $<0.9$ was considered abnormal; however, an ABI of $>1.4$ was excluded.

\section{Statistical Analysis}

Quantitative values were described in terms of means and standard deviations; these were compared by using the Student t-test. The association of variables was evaluated by using SPSS 17.0.

\section{RESULTS}

There were 33 patients with ACS (72.8\% male, $27.2 \%$ female) and 33 patients without ACS $(81.8 \%$ male, $18.2 \%$ female) admitted to the Department of Cardiology and Vascular Medicine of Prof. Dr. R.D. Kandou Hospital, Manado from September to December 2012.

In comparison to those without ACS, patients with ACS were significantly older (57.0 years vs. 52.3 years; $P<0.001$ ), and had a higher prevalence of hypertension history $(64.9 \%$ vs. $35.1 \% ; P<0.005)$, a higher prevalence of smoking history (69.0\% vs. $31.0 \% ; P<0.001)$, and a higher prevalence of cardiovascular disease history $(72.2 \%$ vs. $27.8 ; P<0.001)$. The ACS patients had a significantly higher prevalence of abnormal ABI $(82.1 \%$ vs. $17.9 \% ; P<0.001)$. The chi-square test showed that ACS events were associated with an increased risk of abnormal $\mathrm{ABI}$ with an odds ratio of 12.88 (95\% CI : 3.8543.06; $P<0.01)$.

\section{DISCUSSION}

This study showed that ACS was associated with an increased risk of abnormal ABI. It was found that $82.2 \%$ of the patients had abnormal ABI which was significantly higher than of those without ACS. Moreover, ACS events were also associated with an increased risk of 
Table 1. ABI Crosstabulation

\begin{tabular}{|c|c|c|c|c|c|}
\hline \multicolumn{6}{|c|}{ ABI Crosstabulation } \\
\hline & & & & $\mathrm{CS}$ & Total \\
\hline & & & ACS & Non-ACS & \\
\hline \multirow{4}{*}{$\mathrm{ABI}$} & \multirow{2}{*}{ Abnormal } & Count & 23 & 5 & 28 \\
\hline & & $\%$ within $\mathrm{ABI}$ & $82.1 \%$ & $17.9 \%$ & $100.0 \%$ \\
\hline & \multirow{2}{*}{ Normal } & Count & 10 & 28 & 38 \\
\hline & & $\%$ within $\mathrm{ABI}$ & $26.3 \%$ & $73.7 \%$ & $100.0 \%$ \\
\hline & \multirow{2}{*}{ Total } & Count & 33 & 33 & 66 \\
\hline & & $\%$ within $\mathrm{ABI}$ & $50.0 \%$ & $50.0 \%$ & $100.0 \%$ \\
\hline
\end{tabular}

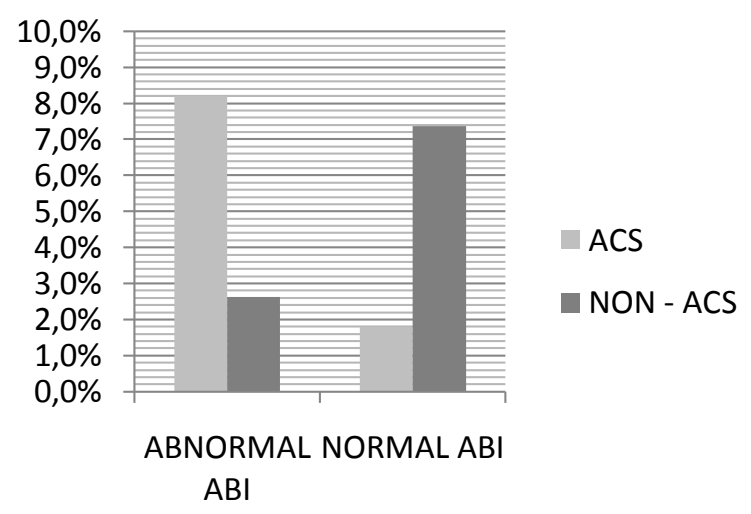

Figure 1. Comparison of $\mathrm{ABI}$ in patients with and without ACS

abnormal ABI with an odds ratio of 12.88 . In a previous study, the prevalence of coronary artery diseases among abnormal ABI ranged from $10.5-71 \%$ and the odds ratio ranged from 1.4-3.0. ${ }^{2}$ The higher prevalence of abnormal ABIs in our study might be influenced by the older age of patients who had a higher prevalence of hypertension, coronary artery disease, and smoking. ${ }^{3,4}$

In several studies, a low ABI was associated with cardiovascular risk factors, including hypertension, diabetes mellitus, dyslipidemia, smoking history, and several more recently identified cardiovascular risk factors (eg, C-reactive protein, interleukin6, homocysteine, and chronic kidney diseases). ${ }^{4}$ A lower ABI is associated with an increased risk of myocardial infarction, stroke, and both total and cardiovascularrelated mortalities. ${ }^{2-4}$ Earlier studies have shown that in the assessment of primary risks, an abnormal ABI was a predictor of cardiovascular events in the long term. ${ }^{5}$ Albeit, the association between abnormal ABI and adverse outcomes is determined by an overall greater atherosclerotic burden, greater inflammation, inadequate management of risk factors, or all of these together; it remains to be elucidated.,

\section{CONCLUSION}

ACS was associated with an increased risk of abnormal ABI.

Presented as a Poster Presentation at the 22nd Annual Scientific Meeting of Indonesian Heart Association (Asmiha), Jakarta, Indonesia, April 5-7, 2013.

\section{REFERENCES}

1. ESC Guidelines on the diagnosis and treatment of peripheral artery diseases. European Heart Journal. 2011;32:2851906.

2. Heald CL, Fowkes FG, Murray GD, Price JF. Risk of mortality and cardiovascular disease associated with the ankle-brachial index: Systematic review. Atherosclerosis. 2006;189:61-9.

3. Diehm C, Lange S, Darius H, Pittrow D, von Stritzky B, Tepohl G, et al. Association of low ankle brachial index with high mortality in primary care. Eur Heart J. 2006;27:1743-9.

4. Resnick HE, Lindsay RS, McDermott MM, Devereux RB, Jones KL, Fabsitz RR. Relationship of high and low ankle brachial index to all-cause and cardiovascular disease mortality: the Strong Heart Study. Circulation. 2004;109:733-9. 
5. Marso SP, Hiatt WR. Peripheral arterial disease in patients with diabetes. J Am Coll Cardiol. 2006;47:921-9.

6. Hirsch AT, Haskal ZJ, Hertzer NR, Bakal CW, Creager MA, Halperin JL, et al. ACC/AHA 2005 Practice Guidelines for the management of patients with peripheral arterial disease (lower extremity, renal, mesenteric, and abdominal aortic): a collaborative report from the American Association for Vascular Surgery/Society for Vascular Surgery, Society for Cardiovascular Angiography and Interventions, Society for Vascular
Medicine and Biology, Society of Interventional Radiology, and the ACC/AHA Task Force on Practice Guidelines (Writing Committee to Develop Guidelines for the Management of Patients with Peripheral Arterial Disease): endorsed by the American Association of Cardiovascular and Pulmonary Rehabilitation; National Heart, Lung, and Blood Institute; Society for Vascular Nursing; TransAtlantic InterSociety Consensus; and Vascular Disease Foundation. Circulation. 2006;113:e463-e654. 